\title{
Frequent allelic losses at 11q24.1-q25 in young women with breast cancer: association with poor survival
}

\author{
M Gentile', K Olsen², M Dufmats ${ }^{1}$ and S Wingren ${ }^{1}$ \\ 'Department of Biomedicine and Surgery, Division of Oncology and 2Department of Health and Environment, Division of Pathology and Forensic Medicine, \\ Faculty of Health Sciences, University Hospital, S-581 85 Linköping, Sweden
}

\begin{abstract}
Summary Previous studies have demonstrated that the pathological features of breast cancer are more aggressive in younger women than in their older counterparts, and that young age may be an independent marker for adverse prognosis. These findings have raised the question whether these differences are also present at the molecular level. In order to characterize the genetic alterations associated with early-onset breast cancer, 102 cases selected for age under 37 at diagnosis were examined for loss of heterozygosity (LOH) at nine different loci on chromosomes 11,13 and 17 . Ninety cases (88\%), exhibited LOH for at least one marker. The D17S855 marker, intragenic in the BRCA1 gene, showed a high proportion of $\mathrm{LOH}(63 \%)$, whereas the intragenic marker for the TP53 gene, HP53, exhibited LOH in $43 \%$ of the cases. On chromosome 11, frequencies of LOH peaked at the D11S969 and D11S387 markers, which expressed LOH in $53 \%$ and $48 \%$ of the informative cases, whereas D11S1818, which is proximate to the ATM gene, exhibited an LOH frequency of $24 \%$. A statistically significant correlation was found between LOH at the D11S387 marker and poor survival $(P=0.028)$. No such correlation was found for the adjacent D11S969 marker, located approximately $500 \mathrm{~kb}$ centromeric to D11S387. We conclude that one or more as yet unidentified genes, situated in chromosome bands 11q24.1-q25, could be involved in the initiation and/or progression of breast cancer in younger women.
\end{abstract}

Keywords: early onset breast cancer; young age; poor prognosis; LOH analysis; 11q24.1-q25

Several investigators have reported that breast cancer in younger women, when compared to their older counterparts, exhibits more aggressive features including larger tumour size, presence of positive lymph nodes, absence of steroid receptors and a high $\mathrm{S}$ phase fraction (Wenger et al, 1993; Albain et al, 1994; Walker et al, 1996). Furthermore, young age has been shown to be an independent predictor of adverse prognosis (de la Rochefordiere et al, 1993; Albain et al, 1994; Bonnier et al, 1995), a finding that has resulted in speculation that early-onset breast carcinomas may be of a biologically different origin and therefore should be regarded as a separate disease (Adami et al, 1986; Host and Lund, 1986; de la Rochefordiere et al, 1993; Chung et al, 1996).

To date, most studies concerning genetic characterization of breast cancer have not considered the age distribution of the studied patient population, hence, knowledge about possible agedependent differentials at the molecular level is still scarce. Accordingly, the present study was undertaken with intent to investigate and characterize the genetic alterations associated with breast cancer in younger women. For this purpose, we performed loss of heterozygosity $(\mathrm{LOH})$ analysis, using nine different highly polymorphic microsatellite markers located on chromosomes 11 , 13 and 17. These were selected to determine the involvement of several putative tumour suppressor loci previously shown to be implicated in breast cancer.

On chromosome 11, markers mapping closely or telomeric to the recently cloned ATM gene (Savitsky et al, 1995) were

Received 31 March 1998

Revised 4 December 1998

Accepted 4 December 1998

Correspondence to: M Gentile included. Individuals who are heterozygous for the ATM locus, exhibit an increased sensitivity to ionizing radiation and predisposition to breast cancer (Swift et al, 1987, 1991, 1994; Sanford et al, 1990). Easton et al (1994) estimated that 3.8\% of all female breast cancer cases, and as many as $8 \%$ of early-onset cases (i.e. afflicting women under the age of 40), could be due to heterozygous mutations in the ATM gene. The role of ATM in the processes associated with cell cycle control is still unclear, although Westphal et al (1997) recently suggested that the proteins expressed by ATM and TP53 might cooperate in apoptosis and suppression of tumorigenesis.

The markers selected on chromosome 13 are found in close proximity to the $B R C A 2$ and the $R B 1$ genes. The protein coded by the $B R C A 2$ gene, has been implied to have a protective role in cell proliferation (Vaughn et al, 1996), and mutations in the gene sequence have been reported to be responsible for a large portion of hereditary breast cancer cases (Wooster et al, 1995; Phelan et al, 1996; Tavtigian et al, 1996). Numerous investigators have shown that the $R B 1$ gene is frequently heterozygously lost in breast cancer (Devilee et al, 1991; Andersen et al, 1992; Borg et al, 1992). The RB protein has a significant role in cell proliferation and is known to be involved in restriction-point control and $\mathrm{G}_{1} / \mathrm{S}$ phase transition during the cell cycle (Sherr, 1996).

Various tumour suppressor genes located on chromosome 17 are involved in tumour development and/or progression of breast cancer. In the present study, $\mathrm{LOH}$ was assessed for a number of these genes, including TP53, BRCA1 and NME1. The protein product of TP53 plays a central role in cell proliferation, arresting the cell cycle in the $G_{1}$ phase to allow repair of the DNA in response to DNA damage. The TP53 gene has been shown to be implicated in the majority of cancer forms (Nigro et al, 1989; 
Hollstein et al, 1991; Greenblatt et al, 1994), and the incidence of TP53 mutations in breast cancer has been found to be higher in young patients (Caleffi et al, 1994). The role of BRCAl in the cell cycle has not yet been elucidated, although it has been proposed that the protein of this gene may be significant for the maintenance of the integrity of the genome and that it may interact with Rad51 (Scully et al., 1997), which in turn is known to interact with p53 (Stürzbecher et al, 1996). Recently, Jensen et al (1998) demonstrated that physical interaction between BRCA1 and a novel ubiquitin hydrolase named BAP1, enhanced BRCA1-mediated cell growth suppression. Mutations in BRCA1 and BRCA2 are presumed to underlie the majority of inherited breast cancer cases (Miki et al, 1994; Szabo et al, 1995). The protein coded by the NME1 gene has been reported to exhibit metastatic suppression capabilities (Leone et al, 1991, 1993), and reduced NME1 expression has been demonstrated to be significantly associated with aggressive tumour behaviour (Bevilacqua et al, 1989; Hennessy et al, 1991).

\section{MATERIALS AND METHODS}

\section{Patients}

The study included 102 young female breast cancer patients diagnosed in the South-East Sweden Health Care Region, between 1980 and 1993. The patients were between 24 and 36 years of age at the time of diagnosis, with a median age of 34 . Survival data were available from the Cause of Death Register provided by the National Board of Health and Welfare. At the final follow-up, 38 patients were reported to be deceased due to breast cancer; the median follow-up time was 67 months. Tissue samples from archival material were obtained from the pathology departments of hospitals in Linköping, Norrköping, Jönköping and Kalmar.

\section{DNA isolation}

Tumour sections were selected from routinely stained formalinfixed and paraffin-embedded material. In a minority of cases the tumour sections also contained parts of normal breast parenchyme which was removed before DNA extraction. Each case was matched with normal cells from a lymph node that was free of metastasis. A slightly modified standard procedure (Shibata et al,
1989) was used for extracting the DNA. Paraffin was removed by repeated extractions with xylene, followed by washing with decreasing concentrations of ethanol. The tissue was digested with $10 \mathrm{mg} \mathrm{ml}^{-1}$ proteinase $\mathrm{K}$ (Boehringer-Mannheim) in a digestion buffer containing $8 \mathrm{~mm}$ Tris- $\mathrm{HCl}$ (pH 8.0), $0.8 \mathrm{~mm}$ EDTA, $80 \mathrm{~mm}$ sodium chloride and $2 \%$ sodium dodecyl sulphate (SDS). Digestion was carried out at $55^{\circ} \mathrm{C}$ for $36 \mathrm{~h}$. Remaining enzymes were inactivated by heating the samples at $95^{\circ} \mathrm{C}$ for $10 \mathrm{~min}$. By-products of the enzymatic digestion were removed from the nucleic acids by extraction with phenol, phenol-chloroform (1:1) and chloroform. DNA was precipitated by adding $95 \%(\mathrm{v} / \mathrm{v})$ ethanol to a final concentration of $65 \%(\mathrm{v} / \mathrm{v})$ and sodium acetate to a final concentration of $0.1 \mathrm{M}$, and then incubating at $-70^{\circ} \mathrm{C}$ for $1 \mathrm{~h}$. The DNA was pelleted by centrifugation at $12000 \mathrm{~g}$ at $0^{\circ} \mathrm{C}$ for $1 \mathrm{~h}$ and salt residues were subsequently removed by washing with $70 \%$ ethanol. Nucleic acids were repelleted by centrifuging as above for $5 \mathrm{~min}$ and then vacuum-dried and resuspended in sterile double-distilled water.

\section{LOH analysis}

Nine highly polymorphic microsatellite markers were used, mapping on chromosome arms 11q, 13q, 17p and 17q (Table 1). The estimated cytogenetic order of these markers was as follows: 11-cenD11S1818-D115969-qtr, 13-cen-D13S260-D13S267-D13S263-qtr and 17ptr-HP53-cen-NM23-H1-D17S855-qtr. Complete sequence and chromosomal localization for the markers were obtained from the GDB ${ }^{\mathrm{TM}}$ Human Genome Database (online), Johns Hopkins University, Baltimore, MD, USA, URL: http://gdbwww. gdb.orgl.

Polymerase chain reaction (PCR) was performed in a total reaction volume of $22 \mu$, containing 25-50 ng of genomic DNA, $2 \mathrm{~mm}$ magnesium chloride, $1 \times$ Taq Polymerase buffer solution (20 mM $\left(\mathrm{NH}_{4}\right)_{2} \mathrm{SO}_{4}, 75 \mathrm{~mm}$ Tris- $\mathrm{HCl}$ (pH 8.5), 0.1\% Tween 20), $1 \mu \mathrm{M}$ of each primer, $0.2 \mathrm{~mm}$ of each dNTP and $0.5 \mathrm{u}$ Taq Polymerase (SDS/Promega). Annealing conditions were optimized specifically for each pair of primers (Table 1), but the denaturation and extension steps were the same for all markers and were performed at $94^{\circ} \mathrm{C}$ for $30 \mathrm{~s}$ and $72^{\circ} \mathrm{C}$ for $45 \mathrm{~s}$ respectively. PCR products were confirmed by agarose $(2 \%)$ gel separation and ethidium bromide staining and subsequently subjected to radioactive labelling with PCR by incorporation of $\alpha$-dATP ${ }^{32}$. Labelling conditions were identical to those used for the primary PCR,

Table 1 Chromosomal localization, average size and frequency of heterozygosity of the nine different markers. Annealing temperatures and corresponding number of cycles used for PCR amplification are also included

\begin{tabular}{|c|c|c|c|c|c|}
\hline Locus symbol & Chromosomal localization ${ }^{a}$ & Size (bp) ${ }^{a}$ & Heterozygosity (\%)a & Annealing temperature $\left({ }^{\circ} \mathrm{C}\right)$ & Number of cycles \\
\hline D11S1818 & $11 q 22-23$ & $140-170$ & 70 & 55 & 35 \\
\hline D11S969 & $11 q 24.1-25$ & $141-149$ & 76 & 55 & 40 \\
\hline D11S387 & $11 q 25$ & $168-196$ & 85 & 53 & 35 \\
\hline D13S260 & $13 q 12.3$ & $158-173$ & 78 & 55 & 35 \\
\hline D13S267 & $13 q 12.3$ & $148-162$ & 69 & $62 / 58^{b}$ & $10 / 30^{b}$ \\
\hline D13S263 & $13 q 14.1-14.2$ & $145-165$ & 84 & 55 & 35 \\
\hline HP53 & 17p13.1 & $103-135$ & 90 & $68^{c}$ & $35^{c}$ \\
\hline NM23-H1 & $17 q 21.3$ & $\sim 106$ & NA & 55 & 35 \\
\hline D17S855 & $17 q 21$ & $143-155$ & 82 & $58 / 54^{\mathrm{b}}$ & $20 / 20^{b}$ \\
\hline
\end{tabular}

a Data was extracted from the GDB ${ }^{\mathrm{TM}}$ Human Genome Database. ${ }^{\mathrm{b}}$ For the D13S267 and D17S855 markers, PCR was performed at two different annealing temperatures, i.e. 10 cycles at $62^{\circ} \mathrm{C}$ followed by 30 cycles at $58^{\circ} \mathrm{C}$ and 20 cycles at $58^{\circ} \mathrm{C}$ followed by 20 cycles at $54^{\circ} \mathrm{C}$ respectively. ${ }^{\mathrm{c}} \mathrm{PCR}$ was performed using two-step cycles, i.e. the annealing and extension steps were combined to a single elongated step performed at $68^{\circ} \mathrm{C}$. $\mathrm{NA}$, not available. 
Table 2 Frequency of LOH and frequency of death in cases with LOH and ROH observed for the different markers. The association between LOH and poor survival was evaluated using the Log-Rank Test

\begin{tabular}{lrrr}
\hline Locus symbol & $\begin{array}{c}\text { No. of cases with LOH/ } \\
\text { no. of informative cases (\%) }\end{array}$ & $\begin{array}{c}\text { No. of deaths with LOH/ } \\
\text { no. of cases with LOH (\%) }\end{array}$ & $\begin{array}{c}\text { No. of deaths with ROH/ } \\
\text { no. of cases with ROH (\%) }\end{array}$ \\
\hline D11S1818 & $13 / 55(24)$ & $3 / 13(23)$ & $\begin{array}{c}\text { Association between LOH } \\
\text { and poor survival (P-value) }\end{array}$ \\
D11S969 & $29 / 55(53)$ & $12 / 29(41)$ & $22 / 42(52)$ \\
D11S387 & $31 / 65(48)$ & $15 / 31(48)$ & $12 / 26(46)$ \\
D13S260 & $21 / 48(44)$ & $7 / 21(33)$ & $8 / 34(24)$ \\
D13S267 & $10 / 42(24)$ & $3 / 10(30)$ & $6 / 27(22)$ \\
D13S263 & $27 / 79(34)$ & $12 / 27(44)$ & $8 / 32(25)$ \\
HP53 & $20 / 47(43)$ & $7 / 20(35)$ & $17 / 52(33)$ \\
NM23-H1 & $29 / 64(45)$ & $14 / 29(48)$ & $8 / 27(30)$ \\
D17S855 & $26 / 41(63)$ & $10 / 26(38)$ & $11 / 35(31)$ \\
& & NS & $7 / 15(47)$ \\
\hline
\end{tabular}

a NS, not statistically significant, i.e. $P>0.05$. $\mathrm{LOH}$, loss of heterozygosity; $\mathrm{ROH}$, retention of heterozygosity.

except that the number of cycles was decreased to 15 . The different alleles were then separated on a denaturing polyacrylamide $(6 \%)$ gel containing $8 \mathrm{M}$ urea, at $45 \mathrm{~W}$ for $2-3 \mathrm{~h}$. Gels were dried and exposed on X-ray film (Cronex 4, DuPont) using intensifying screens, for $5-40 \mathrm{~h}$ at $-70^{\circ} \mathrm{C}$. The evaluation of $\mathrm{LOH}$ was made by visual inspection by at least two independent investigators. $\mathrm{LOH}$ was considered to have occurred if the signal intensity of one allele in the tumour DNA was significantly reduced, in relation to the other allele, when compared to the signal intensity observed for the alleles in the corresponding normal DNA.

\section{Statistical analysis}

Correlation of allelic losses between pairs of markers was evaluated with the chi-square test. Survival curves were calculated according to the method of Kaplan and Meier (1958). The log-rank test was used to assess differences in patient survival between cases with loss and retention of heterozygosity at the various markers.

\section{RESULTS}

Of the 102 cases, 90 (88\%) exhibited LOH for at least one marker; $40(39 \%), 48(47 \%)$ and 58 (57\%) showed LOH for markers on chromosomes 11, 13 and 17 respectively (Table 2). Autoradiographs showing $\mathrm{LOH}$ for the different markers are illustrated in Figure 1. The intragenic BRCA1 marker D17S855 exhibited the highest proportion of $\mathrm{LOH}(63 \%)$ on chromosome 17 , whereas a lower incidence was observed at the HP53 and NM23-H1 loci. On chromosome 13, the highest proportion of allelic losses was found at the D13S260 marker, which expressed LOH in 44\% of the informative cases. A lower incidence was observed for the D13S263 and D13S267 markers. The frequency of LOH peaked at the D11S969 and D11S387 markers on chromosome 11, affecting $53 \%$ and $48 \%$ of the informative cases, respectively, while LOH at D11S1818 was only observed in $24 \%$ of the cases.

Figure 2 shows the pattern of $\mathrm{LOH}$ and survival among cases where data was available for all markers on each chromosome. No overlapping region of $\mathrm{LOH}$ was found for markers on chromosome 17, with only one case showing loss at all three markers (Figure 2A). Two patients expressed $\mathrm{LOH}$ at all three markers on chromosome 13, whereas the remaining cases exhibited only partial loss with no significant overlap between markers (Figure 2B). An overlapping region of $\mathrm{LOH}$ was found on chromosome

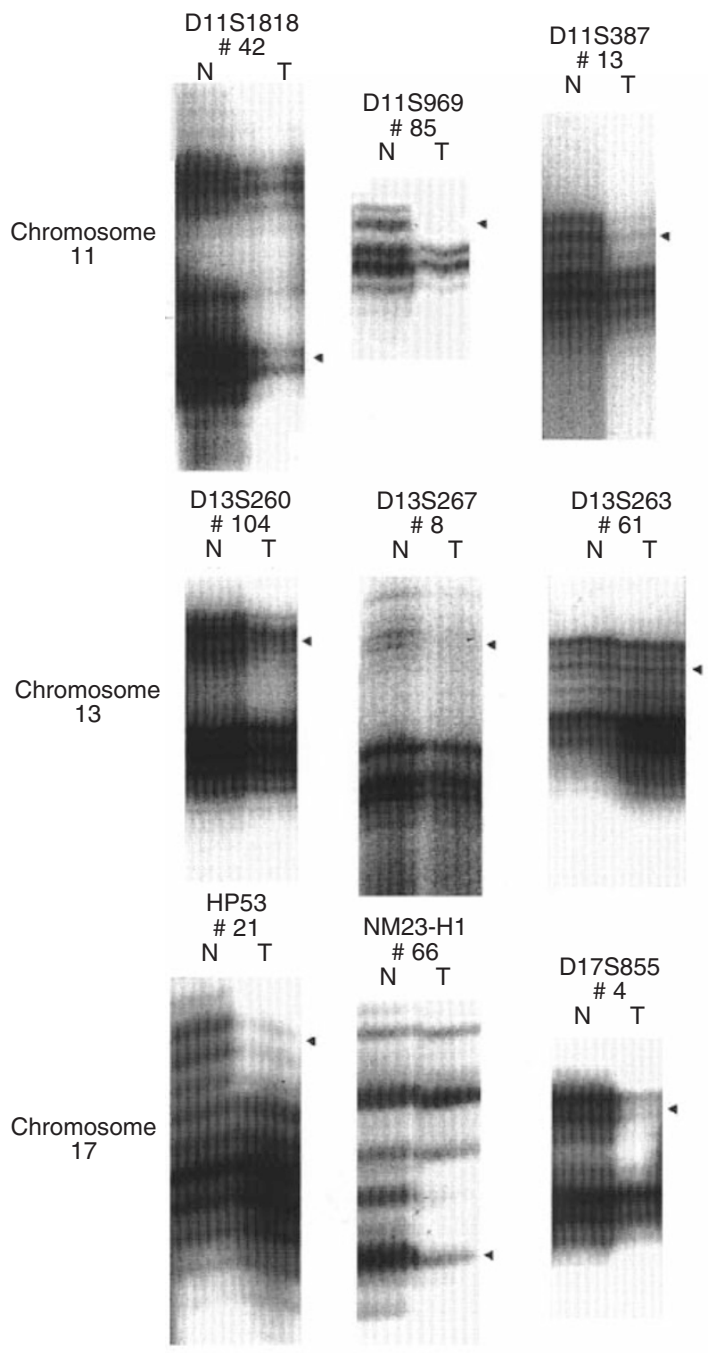

Figure 1 Examples of autoradiographs showing allelic loss (LOH) for the nine different markers. For each case, samples containing normal DNA (N) were loaded adjacent to the matched sample with tumour DNA (T). Arrowheads indicate alleles with reduced relative intensity 
A

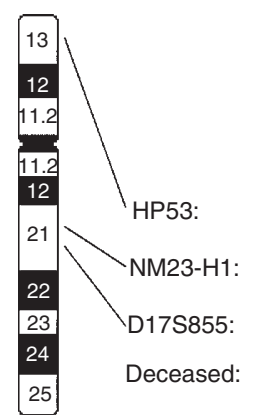

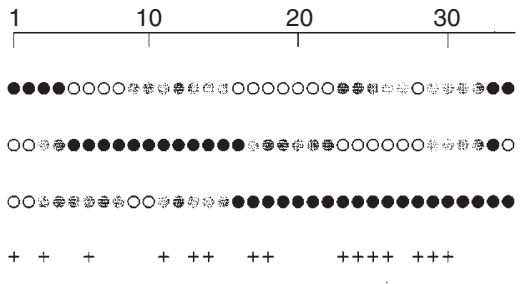

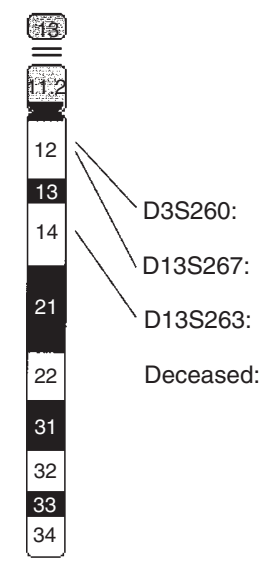

1

$\lceil+1,1 / 20$
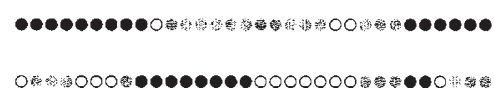

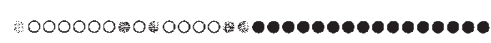
$++++$
30 


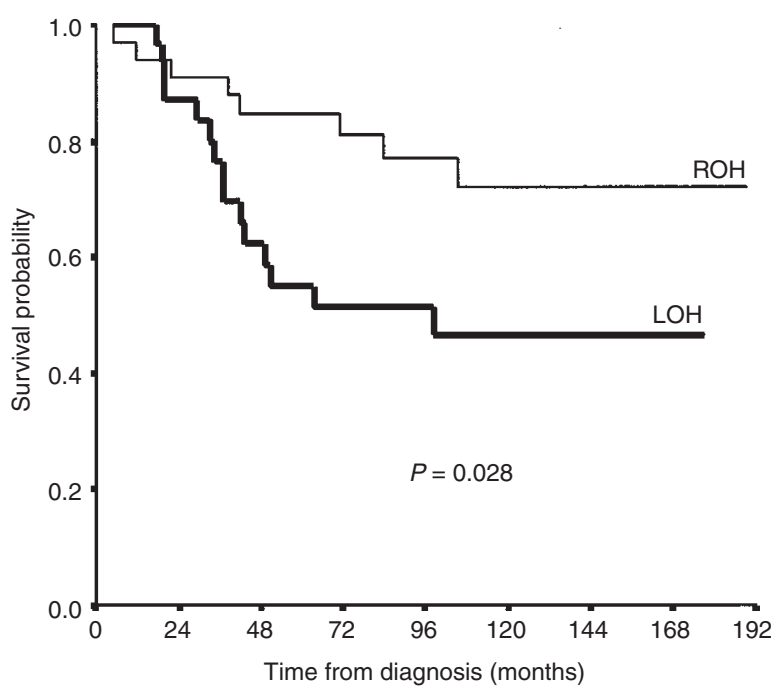

Figure 3 Survival in relation to loss of heterozygosity $(\mathrm{LOH})$ and retention of heterozygosity (ROH) at the D11S387 locus. Deaths due to other causes than breast cancer were censored. The difference in survival between the two groups was statistically significant $(P=0.028)$

confirm that genes located in these regions may play an important role in the pathogenesis of breast cancer in young women. However, we also obtained data suggesting that a previously unidentified gene may be involved in the initiation and/or progression of early-onset breast cancer.

In keeping with several recent investigations performed on breast cancer cases not selected for young age (Gudmundsson et al, 1995; Kerangueven et al, 1997; Koreth et al, 1997), we found a high proportion of allelic losses at the telomere of chromosome 11 (Table 2). The D11S969 and D11S387 markers, located in the 11q24.1-25 region, demonstrated a significant degree of overlap with a breakpoint towards the more centromeric marker D11S1818 (Figure 2C). These findings provide support for the existence of an as yet unidentified tumour suppressor gene or genes, approximately $20 \mathrm{Mb}$ telomeric to $A T M$, that may be involved in the tumorigenic process. Furthermore, log-rank analysis of our data uncovered a statistically significant correlation between $\mathrm{LOH}$ at the D11S387 marker and poor survival, implying that inactivation of this gene(s) may provoke more aggressive tumour behaviour. Recently, Montagna et al (1996) found evidence for the existence of a gene exhibiting sequence homology to the h-PRL-1 gene in the 11q24-q25 region. Interestingly, the h-PRL-1 gene has been suggested to play an important role in the control of basic cellular processes, such as cell growth and proliferation, making the h-PRL-1 homologue a possible candidate gene.

The proportion of $\mathrm{LOH}$ found at the marker for the ATM locus was less than half that found at the D11S969 and D11S387 markers. Moreover, as shown in Table 2, comparing the proportions of death among cases with $\mathrm{LOH}$ and cases with $\mathrm{ROH}$ between the three markers, demonstrated a two- to fourfold increase in breast cancer-specific death for the telomeric markers. These findings suggest a less important role for the ATM gene in early-onset breast cancer than previously postulated. In further support for our results, Fitzgerald et al (1997) recently conducted a case-control study and found that ATM mutations were as common in the control population as in patients with early-onset breast cancer. In addition, Vorechovský et al $(1996 a, 1996 b)$ performed screening of 38 consecutive breast cancer cases, and subsequently on a larger population comprising 88 cases, for ATM mutations and concluded that there was no evidence for an increased number of heterozygous ATM carriers in the investigated population.

Compared with previous investigations of sporadic breast cancer cases not selected for age (Nagai et al, 1995; Beckmann et al, 1996; Kerangueven et al, 1997; Koreth et al, 1997), we observed a higher incidence of LOH at the D17S855 marker, which is located intragenic to BRCA1. This could, in part, reflect the age-dependent distribution of hereditary and non-hereditary cases, which was likely shifted towards a higher proportion of hereditary cases in the studied patient population. Marcus et al (1994) estimated that approximately half of the breast cancer cases in women under the age of 30 are of hereditary origin. It is generally recognized that $B R C A 1$ germ-line mutations account for almost half of the hereditary breast cancer cases (Miki et al, 1994; Easton et al, 1995), suggesting that the number of hereditary cases in the present study is probably not sufficient to satisfactorily explain the high incidence of $\mathrm{LOH}$ at this locus. Assuming a sequence of genetic events following Knudson's (1971) 'two-hit' hypothesis and since somatic mutations in the BRCAl gene appear to be an infrequent event (Futreal et al, 1994; Merajver et al, 1995; Krainer et al, 1997), a plausible interpretation of our findings could be that the surroundings of the D17S855 marker may harbour additional gene(s) that could contribute to the development and/or progression of early-onset breast cancer. It is important to note, however, that the apparent discordance observed in previous studies between BRCA1 mutations and $\mathrm{LOH}$ at the corresponding locus, could imply that BRCAl may lose its tumour suppressor function by down-regulation caused by mechanisms other than structural mutations (Bièche et al, 1997). A recent study by Sourvinos and Spandidos (1998) confirmed this by demonstrating a two- to fivefold reduced BRCA1 expression in tumour specimen as compared to normal tissue. They proposed that the reduction in mRNA levels could be due to loss of gene copies (allelic loss), deletion of regulatory elements in the promoter region of $B R C A 1$ or failure in the transcriptional regulation by oestrogen receptors.

Considering the findings of several previous studies suggesting an association between TP53 status and age (Caleffi et al, 1994; Walker et al, 1996), we anticipated the frequency of LOH at this locus to be higher than what is usually found in consecutive sporadic cases. However, the proportion of cases exhibiting $\mathrm{LOH}$ in the present study falls within the range of what has been previously reported for cases not selected for age (Andersen et al, 1992; Cornelis et al, 1994; Schmutzler et al, 1996; Kerangueven et al, 1997; Niederacher et al, 1997). Furthermore, we found no association between $\mathrm{LOH}$ and poor survival, which is somewhat surprising since Elledge and Allred (1994), in a review of the related literature, concluded that overexpression of $\mathrm{p} 53$ protein as well as mutations in the TP53 gene, are independent markers for adverse prognosis in breast cancer. It is important to note though that these studies analysed TP53 mutations or p53 protein expression, and not $\mathrm{LOH}$ at this locus. Although there are a few studies in which loss of TP53 has been investigated for prognostic significance (Andersen et al, 1992; Nagai et al, 1994; Lizard-Nacol et al, 1997), the small number of cases included in these studies makes it hazardous to draw any definitive conclusions. It is thus unclear whether the lack of association between LOH at the TP53 marker and poor survival noted in these and the present study is of any underlying biological significance, or if it merely reflects the 
limited number of observations assessed by the statistical tests. Alternatively, the discordance between the present report and the review by Elledge and Allred could be explained by the observed LOH occurring due to alterations in gene(s) other than TP53 residing in the $17 \mathrm{p} 13.1$ region.

In conclusion, it appears that one or more previously unidentified genes located in chromosomal band 11q24.1-q25 are implicated in early-onset breast cancer. Further refinement of the deleted region and eventually cloning these genes, thus enabling mutation analysis, may contribute to the understanding and elucidation of the molecular mechanisms that underlie the aetiology of breast cancer in young women.

\section{ACKNOWLEDGEMENTS}

We would like to thank Malin Helgesson and Linda Näslund for valuable technical assistance. We also wish to acknowledge the departments of pathology at the hospitals in Linköping, Norrköping, Jönköping and Kalmar for kindly providing archival material. This work was supported by grants from the Swedish Cancer Society.

\section{REFERENCES}

Adami HO, Malker B, Holmberg L, Persson I and Stone B (1986) The relation between survival and age at diagnosis in breast cancer. $N$ Engl J Med 315: $559-563$

Albain KS, Allred DC and Clark GM (1994) Breast cancer outcome and predictors of outcome: are there age differentials? J Natl Cancer Inst Monogr 16: 35-42

Andersen TI, Gaustad A, Ottestad L, Farrants GW, Nesland JM, Tveit KM and Borresen AL (1992) Genetic alterations of the tumour suppressor gene regions $3 p, 11 p, 13 q, 17 p$ and $17 q$ in human breast carcinomas. Genes Chromosomes Cancer 4: 113-121

Beckmann MW, Picard F, An HX, van Roeyen CR, Dominik SI, Mosny DS, Schnürch HG, Bender HG and Niederacher D (1996) Clinical impact of detection of loss of heterozygosity of BRCA1 and BRCA2 markers in sporadic breast cancer. Br J Cancer 73: 1220-1226

Bevilacqua G, Sobel ME, Liotta LA and Steeg PS (1989) Association of low nm23 RNA levels in human primary infiltrating ductal breast carcinomas with lymph node involvement and other histopathological indicators of high metastatic potential. Cancer Res 49: 5185-5190

Bièche I, Nogues C, Rivoilan S, Khodja A, Latil A and Lidereau R (1997) Prognostic value of loss of heterozygosity at BRCA2 in human breast carcinoma. Br J Cancer 76: 1416-1418

Bonnier P, Romain S, Charpin C, Lejeune C, Tubiana N, Martin PM and Piana L (1995) Age as a prognostic factor in breast cancer: relationship to pathologic and biologic features. Int J Cancer 62: 138-144

Borg A, Zhang QX, Alm P, Olsson H and Sellberg G (1992) The retinoblastoma gene in breast cancer: allele loss is not correlated with loss of gene protein expression. Cancer Res 52: 2991-2994

Caleffi M, Teague MW, Jensen RA, Vnencak-Jones CL, Dupont WD and Parl FF (1994) p53 gene mutations and steroid receptor status in breast cancer. Clinicopathologic correlations and prognostic assessment. Cancer 73: 2147-2156

Chung M, Chang HR, Bland KI and Wanebo HJ (1996) Younger women with breast carcinoma have a poorer prognosis than older women. Cancer 77: 97-103

Cornelis RS, van Vliet M, Vos CB, Cleton Jansen AM, van de Vijver MJ, Peterse JL, Khan PM, Börresen AL, Cornelisse CJ and Devilee P (1994) Evidence for a gene on 17p13.3, distal to TP53, as a target for allele loss in breast tumors without p53 mutations. Cancer Res 54: 4200-4206

de la Rochefordiere A, Asselain B, Campana F, Scholl SM, Fenton J, Vilcoq JR, Durand JC, Pouillart P, Magdelenat H and Fourquet A (1993) Age as prognostic factor in premenopausal breast carcinoma. Lancet 341: 1039-1043

Devilee P, van Vliet M, Bardoel A, Kievits T, Kuipers-Dijkshoorn N, Pearson PL and Cornelisse CJ (1991) Frequent somatic imbalance of marker alleles for chromosome 1 in human primary breast carcinoma. Cancer Res 51: 1020-1025

Easton DF (1994) Cancer risks in A-T heterozygotes. Int J Radiat Biol 66: S177-S182
Easton DF, Ford D and Bishop DT (1995) Breast and ovarian cancer incidence in BRCA1-mutation carriers. Breast Cancer Linkage Consortium. Am J Hum Genet 56: 265-271

Elledge RM and Allred DC (1994) The p53 tumor suppressor gene in breast cancer. Breast Cancer Res Treat 32: 39-47

FitzGerald MG, Bean JM, Hegde SR, Unsal H, MacDonald DJ, Harkin DP, Finkelstein DM, Isselbacher KJ and Haber DA (1997) Heterozygous ATM mutations do not contribute to early onset of breast cancer [see comments]. Nat Genet 15: 307-310

Futreal PA, Liu Q, Shattuck-Eidens D, Cochran C, Harshman K, Tavtigian S, Bennett LM, Haugen-Strano A, Swensen J and Miki Y (1994) BRCA1 mutations in primary breast and ovarian carcinomas. Science 266: 120-122

Greenblatt MS, Bennett WP, Hollstein M and Harris CC (1994) Mutations in the p53 tumor suppressor gene: clues to cancer etiology and molecular pathogenesis. Cancer Res 54: 4855-4878

Gudmundsson J, Barkardottir RB, Eiriksdottir G, Baldursson T, Arason A, Egilsson $\mathrm{V}$ and Ingvarsson S (1995) Loss of heterozygosity at chromosome 11 in breast cancer: association of prognostic factors with genetic alterations. Br J Cancer 72: 696-701

Hennessy C, Henry JA, May FE, Westley BR, Angus B and Lennard TW (1991) Expression of the antimetastatic gene nm23 in human breast cancer: an association with good prognosis. J Natl Cancer Inst 83: 281-285

Hollstein M, Sidransky D, Vogelstein B and Harris CC (1991) p53 mutations in human cancers. Science 253: 49-53

Host H and Lund E (1986) Age as a prognostic factor in breast cancer [published erratum appears in Cancer 1986 Aug 15;58(4):996]. Cancer 57: 2217-2221

Jensen DE, Proctor M, Marquis ST, Gardner HP, Ha SI, Chodosh LA, Ishov AM, Tommerup N, Vissing H, Sekido Y, Minna J, Borodovsky A, Schultz DC, Wilkinson KD, Maul GG, Barlev N, Berger SL, Prendergast GC and Rauscher FJ III (1998) BAP1: a novel ubiquitin hydrolase which binds to the BRCA1 RING finger and enhances BRCA1-mediated cell growth suppression. Oncogene 16: 1097-1012

Kaplan E and Meier P (1958) Non-parametric estimation from incomplete observations. J Am Stat Assoc 53: 457-481

Kerangueven F, Allione F, Noguchi T, Adélaïde J, Sobol H, Jacquemier J and Birnbaum D (1995) Patterns of loss of heterozygosity at loci from chromosome arm $13 q$ suggests a possible involvement of BRCA2 in sporadic breast tumors. Genes Chromosomes Cancer 13: 291-294

Kerangueven F, Eisinger F, Noguchi T, Allione F, Wargniez V, Eng C, Padberg G, Theillet C, Jacquemier J, Longy M and Sobol H (1997) Loss of heterozygosity in human breast carcinomas in the ataxia telangiectasia, Cowden disease and BRCA1 gene regions. Oncogene 14: 339-347

Knudson AG Jr (1971) Mutation and cancer: statistical study of retinoblastoma. Proc Natl Acad Sci USA 68: 820-823

Koreth J, Bakkenist CJ and McGee JO (1997) Allelic deletions at chromosome $11 \mathrm{q} 22-\mathrm{q} 23.1$ and $11 \mathrm{q} 25$-qterm are frequent in sporadic breast but not colorectal cancers. Oncogene 14: 431-437

Krainer M, Silva Arrieta S, FitzGerald MG, Shimada A, Ishioka C, Kanamaru R, MacDonald DJ, Unsal H, Finkelstein DM, Bowcock A, Isselbacher KJ and Haber DA (1997) Differential contributions of BRCA1 and BRCA2 to earlyonset breast cancer. $N$ Engl J Med 336: 1416-1421

Leone A, Flatow U, King CR, Sandeen MA, Margulies IM, Liotta LA and Steeg PS (1991) Reduced tumor incidence, metastatic potential, and cytokine responsiveness of nm23-transfected melanoma cells. Cell 65: 25-35

Leone A, Flatow U, VanHoutte K and Steeg PS (1993) Transfection of human nm23-H1 into the human MDA-MB-435 breast carcinoma cell line: effects on tumor metastatic potential, colonization and enzymatic activity. Oncogene $\mathbf{8}$ : 2325-2333

Lizard Nacol S, Riedinger JM, Lizard G, Glasser AL, Coudray N, Chaplain G and Guerrin J (1997) Loss of heterozygosity at the TP53 gene: independent occurrence from genetic instability events in node-negative breast cancer. Int J Cancer 72: 599-603

Marcus JN, Watson P, Page DL and Lynch HT (1994) Pathology and heredity of breast cancer in younger women. J Natl Cancer Inst Monogr: 23-34

Merajver SD, Pham TM, Caduff RF, Chen M, Poy EL, Cooney KA, Weber BL, Collins FS, Johnston C and Frank TS (1995) Somatic mutations in the BRCA1 gene in sporadic ovarian tumours. Nat Genet 9: 439-443

Miki Y, Swensen J, Shattuck-Eidens D, Futreal PA, Harshman K, Tavtigian S, Liu Q, Cochran C, Bennett LM and Ding W (1994) A strong candidate fo the breast and ovarian cancer susceptibility gene BRCA1. Science $\mathbf{2 6 6}$ : 66-71

Montagna M, Serova O, Sylla BS, Mattei MG and Lenoir GM (1996) Localization of the human phosphotyrosine phosphatase-related genes (h-PRL-1) to 
chromosome bands 1p35-p34, 17q12-q21, 11q24-q25 and 12q24. Hum Genet 98: $738-740$

Nagai MA, Pacheco MM, Brentani MM, Marques LA, Brentani RR, Ponder BA and Mulligan LM (1994) Allelic loss on distal chromosome 17p is associated with poor prognosis in a group of Brazilian breast cancer patients. Br J Cancer 69: $754-758$

Nagai MA, Medeiros AC, Brentani MM, Brentani RR, Marques LA, Mazoyer S and Mulligan LM (1995) Five distinct deleted regions on chromosome 17 defining different subsets of human primary breast tumors. Oncology 52: 448-453

Niederacher D, Picard F, van Roeyen C, An HX, Bender HG and Beckmann MW (1997) Patterns of allelic loss on chromosome 17 in sporadic breast carcinomas detected by fluorescent-labeled microsatellite analysis. Genes Chromosomes Cancer 18: 181-192

Nigro JM, Baker SJ, Preisinger AC, Jessup JM, Hostetter R, Cleary K, Bigner SH, Davidson N, Baylin S and Devilee P (1989) Mutations in the p53 gene occur in diverse human tumour types. Nature 342: 705-708

Phelan CM, Lancaster JM, Tonin P, Gumbs C, Cochran C, Carter R, Ghadirian P, Perret C, Moslehi R, Dion F, Faucher MC, Dole K, Karimi S, Foulkes W, Lounis H, Warner E, Goss P, Anderson D, Larsson C, Narod SA and Futreal PA (1996) Mutation analysis of the BRCA2 gene in 49 site-specific breast cancer families. Nat Genet 13: 120-122

Sanford KK, Parshad R, Price FM, Jones GM, Tarone RE, Eierman L, Hale P and Waldmann TA (1990) Enhanced chromatid damage in blood lymphocytes after G2 phase $\mathrm{x}$ irradiation, a marker of the ataxia-telangiectasia gene. J Natl Cancer Inst 82: 1050-1054

Savitsky K, Bar-Shira A, Gilad S, Rotman G, Ziv Y, Vanagaite L, Tagle DA, Smith S, Uziel T and Sfez S (1995) A single ataxia telangiectasia gene with a product similar to PI-3 kinase. Science 268: 1749-1753

Schmutzler RK, Fimmers R, Bierhoff E, Lohmar B, Homann A, Speiser P, Kubista E, Jaeger K, Krebs D, Zeillinger R, and Wiestler OD (1996) Association of allelic losses on human chromosomal arms 11Q and 16Q in sporadic breast cancer. Int J Cancer 69: 307-311

Scully R, Chen J, Plug A, Xiao Y, Weaver D, Feunteun J, Ashley T and Livingston DM (1997) Association of BRCA1 with Rad51 in mitotic and meiotic cells. Cell 88: 265-275

Sherr CJ (1996) Cancer cell cycles. Science 274: 1672-1677

Shibata D, Brynes RK, Nathwani B, Kwok S, Sninsky J and Arnheim N (1989) Human immunodeficiency viral DNA is readily found in lymph node biopsies from seropositive individuals. Analysis of fixed tissue using the polymerase chain reaction. Am J Pathol 135: 697-702
Sourvinos G and Spandidos DA (1998) Decreased BRCA1 expression levels may arrest the cell cycle through activation of $\mathrm{p} 53$ checkpoint in human sporadic breast tumors. Biochem Biophys Res Commun 245: 75-80

Stürzbecher HW, Donzelmann B, Henning W, Knippschild U and Buchhop S (1996) p53 is linked directly to homologous recombination processes via RAD51/RecA protein interaction. EMBO J 15: 1992-2002

Swift M, Reitnauer PJ, Morrell D and Chase CL (1987) Breast and other cancers in families with ataxia-telangiectasia. N Engl J Med 316: 1289-1294

Swift M, Morrell D, Massey RB and Chase CL (1991) Incidence of cancer in 161 families affected by ataxia-telangiectasia. $N$ Engl J Med 325: 1831-1836

Swift M (1994) Ionizing radiation, breast cancer, and ataxia-telangiectasia [editorial; comment]. J Natl Cancer Inst 86: 1571-1572

Szabo CI and King MC (1995) Inherited breast and ovarian cancer. Hum Mol Genet 4: $1811-1817$

Tavtigian SV, Simard J, Rommens J, Couch F, Shattuck-Eidens D, Neuhausen S, Merajver S, Thorlacius S, Offit K, Stoppa-Lyonnet D, Belanger C, Bell R, Berry S, Bogden R, Chen Q, Davis T, Dumont M, Frye C, Hattier T and Jammulapati S (1996) The complete BRCA2 gene and mutations in chromosome 13q-linked kindreds. Nat Genet 12: 333-337

Vaughn JP, Cirisano FD, Huper G, Berchuck A, Futreal PA, Marks JR and Iglehart JD (1996) Cell cycle control of BRCA2. Cancer Res 56: 4590-4594

Vorechovský I, Luo L, Lindblom A, Negrini M, Webster AD, Croce CM and Hammarström L (1996) ATM mutations in cancer families. Cancer Res 56: $4130-4133$

Vorechovský, I, Rasio D, Luo L, Monaco C, Hammarström L, Webster AD, Zaloudik J, Barbanti-Brodani G, James M and Russo G (1996) The ATM gene and susceptibility to breast cancer: analysis of 38 breast tumors reveals no evidence for mutation. Cancer Res 56: 2726-2732

Walker RA, Lees E, Webb MB and Dearing SJ (1996) Breast carcinomas occurring in young women (<35 years) are different. Br J Cancer 74: 1796-1800

Wenger CR, Beardslee S, Owens MA, Pounds G, Oldaker T, Vendely P, Pandian MR, Harrington D, Clark GM and McGuire WL (1993) DNA ploidy, S-phase, and steroid receptors in more than 127,000 breast cancer patients. Breast Cancer Res Treat 28: 9-20

Westphal CH, Rowan S, Schmaltz C, Elson A, Fisher DE and Leder P (1997) ATM and $\mathrm{p} 53$ cooperate in apoptosis and suppression of tumorigenesis, but not in resistance to acute radiation toxicity. Nat Genet 16: 397-401

Wooster R, Bignell G, Lancaster J, Swift S, Seal S, Mangion J, Collins N, Gregory $\mathrm{S}$, Gumbs C and Micklem G (1995) Identification of the breast cancer susceptibility gene BRCA2. Nature 378: 789-792 